\title{
President's Message: Focusing Efforts on Mental \& Emotional Wellness
}

Dear Colleagues,

I am so pleased to be writing the President's message for our second BHAC Journal edition. This edition is special to me in that it has several articles on mental and emotional well-being of our students, faculty, and staff. As health promotion practitioners and those involved in health promotion efforts, we know how important the topic is. Recently, I attended a national conference for workplace health promotion. The topics associated with mental health: Resiliency, coping, stress management, kindness, gratitude - they were at the forefront of conference presentations and conversations. BHAC will continue these discussions amongst academic institutions, as our students, faculty and staff are challenged by issues, personal to local, national to international. The uniqueness of this edition is including three articles devoted to research on mental health efforts, as well as presenting our first BHAC recommendation endorsement for the mental health of college students. The purpose of the endorsement is to recommend evidence-based strategies and solutions to improving the mental health of the students who are enrolled in classes, and live and work on our college campuses. We hope many of you are able to utilize it. It's the first of many recommendation endorsements to come!

By the launch of this edition, you will have received several BHAC items, including the fall newsletter and the 2016 - 2017 annual report, to share with leadership and colleagues. BHAC grants will have been funded and two webinars will have been conducted. Soon, we will begin a BHAC spotlight article, to share what member institutions are doing at their universities. In addition, we have administrative support and will be hiring a program director to lead our efforts.

The 2017-18 board of directors will continue to work hard for the organization, from the EBP \& Research committee, to the Advisory board, to marketing and membership efforts. It truly takes a village. Our terrific organization will continue to aspire together, leading the charge to improve the lives of millions of people that live, work and visit our institutions of higher learning.

Sincerely,

Megan Amaya, PhD, CHES, AFAA

Director of Health Promotion \& Wellness

Assistant Professor of Clinical Nursing

President, National Consortium for Building Healthy Academic Communities

(C) 2017 Amaya. This article is published under a Creative Commons Attribution-NonCommercial-NoDerivatives 4.0 International License (https://creativecommons.org/licenses/by-nc-nd/4.0/) 